\title{
2008年岩手・宮城内陸地震後の降雨により崩壊が発生した 山地斜面の地形的特徴 \\ Geomorphological characteristics of mountain slopes with landslides induced by rainfalls after the Iwate-Miyagi nairiku earthquake in 2008
}

\author{
村上 亘 ${ }^{\mathrm{a}) *}$ ，大丸(裕武a)，金子守男 ${ }^{\mathrm{b}}$ \\ Wataru MURAKAMI, Hiromu DAIMARU and Morio KANEKO
}

\begin{abstract}
Here, we investigated the topographic characteristics of slopes where a rainfall-induced landslide had occurred after the IwateMiyagi Nairiku Earthquake on June 14, 2008. We compared shaded relief maps, contour maps, and cross sections from LiDAR data measured immediately and 3 months after the earthquake. The landslides were caused by rainfall less than those observed in usual rainfall-induced landslide occurrences. From a comparison of the maps, we observed that prior to landslide occurrence, oval or horseshoe-shaped gentle slopes had formed on the slope after the earthquake and cracks had appeared on these slopes. Similar micro-topographies were observed and checked by field survey on neighborhood slopes without landslide occurrences. From the results of a dynamic cone penetrometer and soil cross section, we determined that the weathering layer of the base rocks (Nc value of 10-30) was relatively thick on the slopes where the cracks had appeared. Further, it became clear that a weak layer ( $\mathrm{Nc}$ value below 5) had formed in the weathering layer or near the border with the lower hard layer (Nc value over 40). Therefore, we consider that the weak layer became a slip plane and subsequently, landslide occurred despite lesser rainfall than that normally observed after an earthquake.

Key words : LiDAR, landslide, gentle slope, crack, the Iwate-Miyagi nairiku earthquake in 2008

\section{和文要旨}

2008年 6 月 14 日に発生した岩手・宮城内陸地震の直後，および 3 ヶ月後の 9 月に計測された航空レーザー測量データより作成し た陰影図, 等高線図, 断面図を比較し, 地震後の降雨により崩壊が発生した斜面の崩壊前の地形的な特徵を調査するとともに, 調 查結果をもとに同様な地形的特徵を持つ斜面を抽出し，現地で確認した。地震後の崩壊は通常より少ない降雨で発生していた。崩 壊が発生した斜面では，崩壊発生前は楕円あるいは馬蹄形の緩斜面が存在し，そこに地震によって亀裂が発生していたと判断され た。この地形的な特徵は, 近傍の崩壊が発生していない斜面において同様な地形を判読し, 現地調查から複数の斜面で亀裂の発生 を確認したことで確かめられた。亀裂が発生している斜面では，貫入試験と土層断面調查の結果から $\mathrm{Nc}$ 值が10 30の風化層が比較 的厚く，風化層内あるいは下層の $\mathrm{Nc}$ 值が 40 以上の硬い層との境界付近に $\mathrm{Nc}$ 值が 5 以下の軟弱な層が形成されており，地震後に崩壊 が発生した斜面ではそれらをすべり面としてその後の降雨によって崩壊が発生したことが推測された。

キーワード：航空レーザー測量, 崩壊, 緩斜面, 亀裂, 2008年岩手・宮城内陸地震
\end{abstract}

\section{1.はじめに}

地震にともなう山地斜面の崩壊現象については多くの 調査研究が報告されている（川邊, $1987 ;$ 横山・菊山, 1997など)。また, 1995年の阪神淡路大震災（M7.3）以 降，地震後の降雨などによる 2 次災害の危険性も指摘さ れ，注意を促す報告も多くみられる（田結庄・藤田， 1996 ; 冨田ほか, 1996 ; 沖村ほか, 1998 ; 西村・海堀, 2002など)。これらの調査報告は地震発生後, 数ヶ月か ら1，2年までに発生した事例にとどまるが，これは発生 した崩壊と地震との因果関係が地震から時間が経過する にしたがいはっきりしなくなるためと思われる。しかし， 崩壊地を調査すると, 以前の地震の際に発生したと判断 される亀裂の存在が確認される等, 地震によって脆弱化 した斜面が数年後の降雨により崩壊する可能性が指摘さ れている(小山ほか 2009 ; 村上ほか, 2009 ; 村上ほか, 2013a）。このため，地震により脆弱化した斜面を速やか

* 連絡著者/corresponding author

a ）国立研究開発法人森林総合研究所森林防災研究領域

Forestry and Forest Products Research Institute

Forestry and Forest Products Research
厂 $305-8687$ 茨城県つくば市松の里 1

1 Matsunosato, Tsukuba, Ibaraki, Japan.

b) 林野庁東北森林管理局

Forestry Agency, Tohoku Regional Forest Office
に抽出し評価することが，防災の面から必要であると考 える。

近年，航空レーザー測量の発達により，従来よりも高 精度な地形デー夕をえることが可能となってきている (秋山, 1997)。そして, 複数の時期に計測された航空レー ザー測量データを比較することにより，地震による亀裂 の発生のような斜面内の微地形の形成, あるいは斜面全 体の変形を捉える事が可能となってきている（村上ほか, 2013b)。

本研究では2008年 6 月 14 日に発生した岩手・宮城内陸 地震（M7.2）の際に，多くの斜面崩壊が発生した岩手 県一関市槻木平地区に扔いて, 地震直後と 3 ケ月後に計 測された航空レーザー測量データを比較し, 地震から 3 ケ月後までに新たに崩壊が発生した斜面の地震直後, すなわち崩壊前の地形的特徵について報告する。あわせ て, 検討結果を基に今後, 崩壊の発生する危険性の高い 斜面を推測し，現地で確認した結果についても報告する。

\section{2. 調査地の概要}

調查地である岩手県一関市槻木平地区は2008年岩手． 
宮城内陸地震の震央より $1 \mathrm{~km}$ ぼ南に位置し，地震で 崩落した祭畤大橋より北東に約 $500 \mathrm{~m}$ 離れた場所に位置 する（図-1)。調査地付近の地質は第三紀中新世後期 の海成層（シルト岩，砂岩および凝灰岩）である（栗駒 山地熱地質グループ, 1986)。調査地およびその周辺には 地震にともなう崩壊が多数確認される。調查地付近の地 震直後と地震から 3 ケ月経過した空中写真 (オルソ画像) を図ー 2 に示す。村上ほか（2013a）は調査地周辺でお こなった写真判読から, 地震から 3 ケ月経過した時点で, 崩壊地の拡大や新たな崩壊の発生により崩壊地は地震直 後より 13. 4ha増加し, このうちの $31 \%$ が新規崩壊であっ たことを報告している。この間の調査地域周辺の降雨量 としてAMeDAS臨時観測点「厳美」の降雨データを図 - 3 に示す。期間中の降雨は日降雨量で最大 $84.5 \mathrm{~mm}$ ( 8 月24日観測, 時間最大雨量： $8 \mathrm{~mm})$, 時間最大雨量は

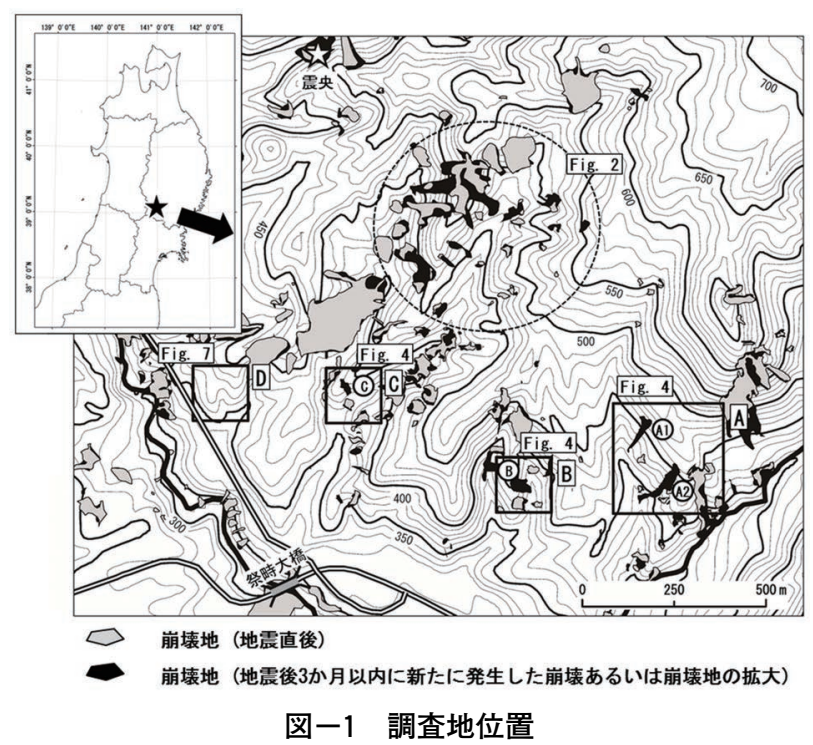

Fig. 1 Study Area

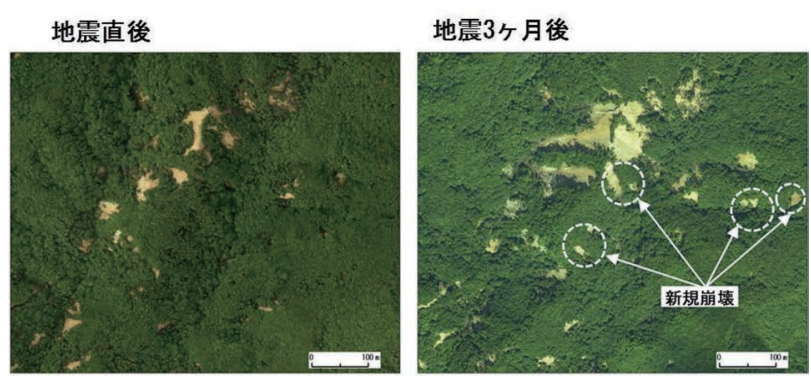

図一2 地震直後の崩壊の分布と 3 ヶ月後の新規崩壊の発生。 空中写真 (オルソ画像) は2008年 6 月14日の地震直 後および 3 ヶ月後の2008年 9 月に林野庁により撮影 された。撮影範囲は図一1に示す。

Fig. 2 Distribution of landslides immediately after the earthquake, and the occurrence of new landslides within 3 months of the earthquake. Aerophotographs (ortho images) were taken by the Forestry Agency in June (immediately after the earthquake) and September ( 3 months after the earthquake). The geographical range of the photos is shown in Fig. 1.
$32 \mathrm{~mm}$ ( 7 月 12 日観測) であった。調查地近傍のAMeDAS 観測点「祭畤」および臨時観測点「厳美」の観測開始か ら現在までの降雨データの解析から, 日雨量はこの地域 において年 1 回程度の確率降雨, 時間最大雨量は 2 年以 上 5 年以下の確率降雨であった。調査地周辺で土砂災害 が発生した最近の豪雨は, 2002年 7 月 9 日〜 12日の台風 6 号にともなうもの (牛山, 2002) だが, その際の雨量 はAMeDAS観測点「一関」において $172 \mathrm{~mm}$ (24時間最 大,「祭畤」では $160 \mathrm{~mm}$ ) であり, 本調査期間中の降雨 量はこの時の半分程度であった。また，野口ほか(2012) は先行土湿指数 (ASI30) の算出結果より, 地震直後か ら 3 ケ月間のASI30は過去に記録した多雨・多雪年時に は至っていないことを報告している。以上のことから， 地震後に新たに確認された崩壊は従来この地域では崩壊 が発生してこなかった雨量で崩壊が発生したことを示す ものと考える。

\section{3. 研究方法}

本調査では，林野庁東北森林管理局より提供していた だいた地震直後と地震 3 ケ月後の 2008 年 9 月に実施した 航空レーザー測量よりえられた 2 時期の地形デー夕，お よび測量と同時に撮影され, オルソ化された空中写真画 像（解像度：72dpi）を使用した。航空レーザー測量デー 夕は樹木等を除去（フィルタリング処理）したランダム なグラウンドデータを解析に使用した。まず，空中写真 画像の比較から, 地震後に新たに崩壊が発生した箇所を 判読した。判読された崩壊斜面のうち, 図ー 4 に示す地 震後に新たに崩壊が発生した斜面 4 ヶ所（A $1-\mathrm{C}$; そ れぞれの位置は図－1を参照）について，崩壊前の地形 的特徵を 2 時期の地形デー夕の比較, および現地調査か ら明らかにした。地形データはArcGIS10.2において上 記のグラウンドデータから $1 \mathrm{~m}$ 解像度のDEMをそれぞ れ作成し，それらを基に陰影図（光源方位： $315^{\circ}$ ，光源 高度： $45^{\circ}$ ), 等高線図（1 m間隔）および断面図を作成

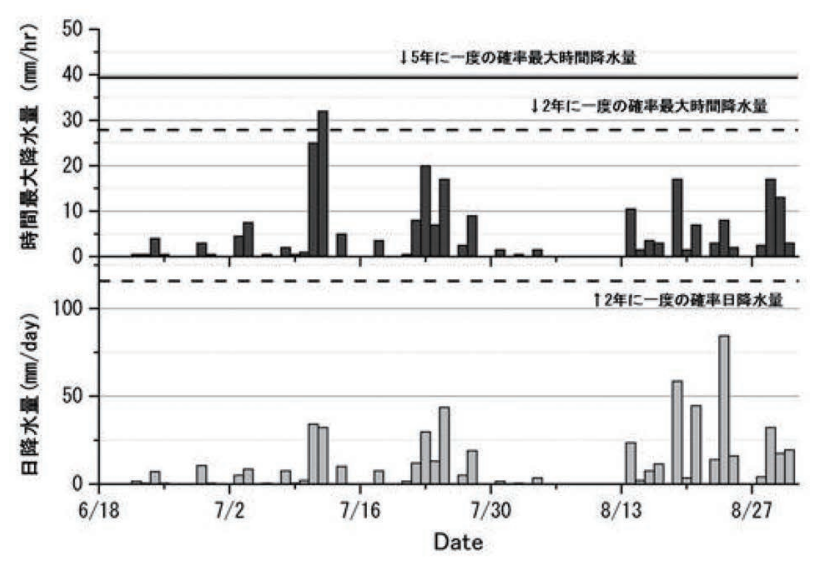

図－3 地震発生以降の降雨量（観測地点：AMeDAS臨時観 測点「厳美」)

Fig. 3 Precipitation during the 3 months after the earthquake 

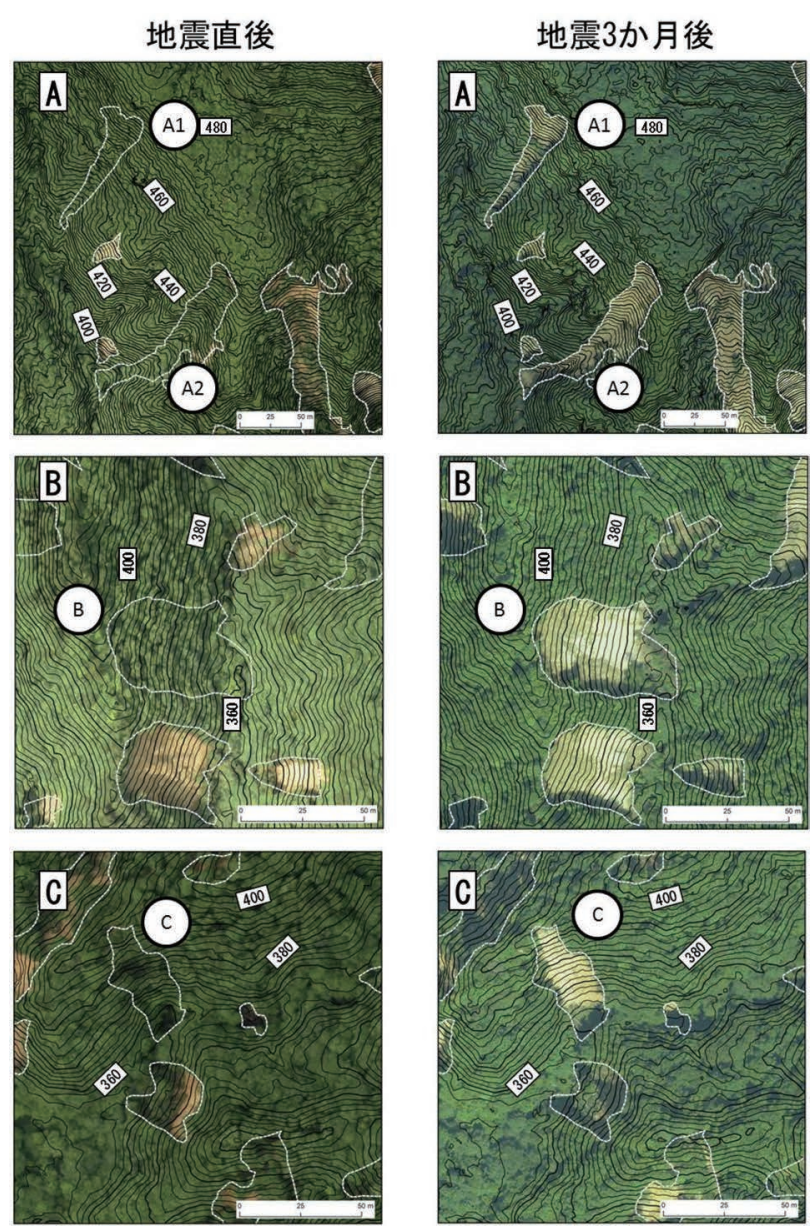

白破線枠 : 地震3ヶ月後の崩壊範囲

図一4 地震後に崩壊が発生した斜面（左写真：地震直後（崩 壊前), 右写真：地震 3 か月後 (崩壊後))。写真内の A 1 〜で示した箇所において, 地震後に崩壊が発生 した。

Fig. 4 Photos of slopes on which landslides occurred after the earthquake. Left: immediately after the earthquake (prior to landslide occurrence). Right : 3 months after the earthquake (after landslide occurrence). On the area $A 1, A 2, B$ and $C$ in the slopes, landslides occurred after the earthquake.

\section{して比較した。}

調査結果を基に，崩壊が発生していない斜面において 崩壊発生地点と同じ地形的特徵をもつ領域を判読し，現 況を調査するために現地を踏査した。現地では土層構造 の特徵を調べるために，簡易貫入試験を行うとともに， 掘削して土層構造を調査した。

\section{4. 調査結果}

4.1 地震後に崩壊が発生した斜面の地形的な特徵 地震後に崩壊が発生した複数の斜面における地震発生 直後，すなわち崩壊が発生する前の等高線図および崩壊 前後の断面図を図 - 5 および 6 に示す。対象斜面におい て地震後に崩壊が発生した場所では, 図 - 5 の等高線図 でみると崩壊前はほぼ直線型の斜面形の中に幅, 長さが 10〜20m程度の半月または馬蹄形の局所的な緩斜面, 図
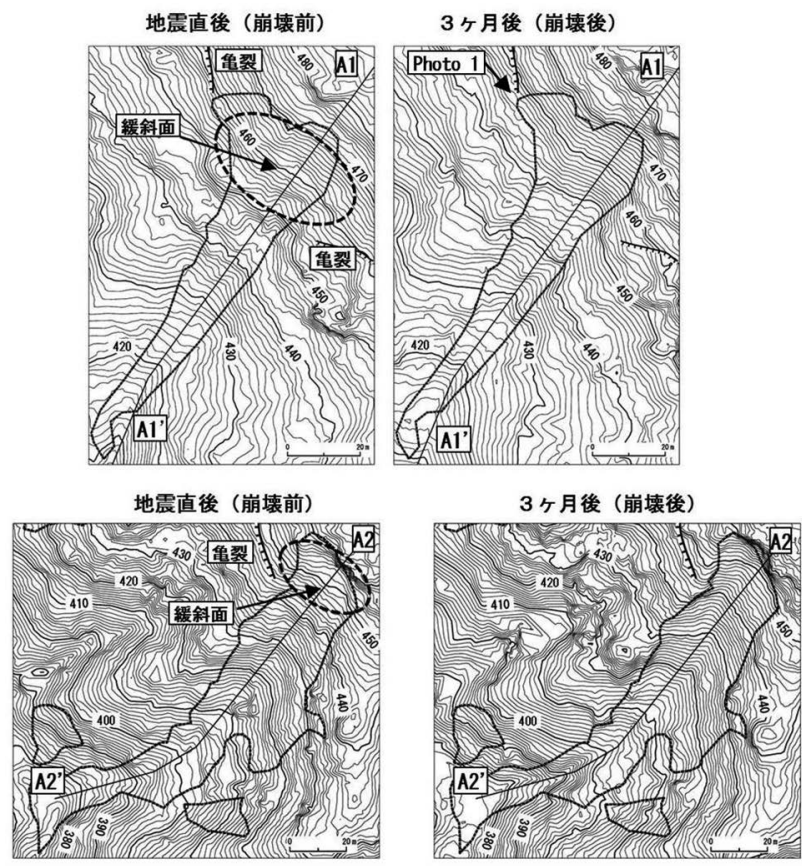

$\cdots$ 地震 3 ヶ月後の崩壊範囲

図一5a 地震後に崩壊した斜面の崩壊前後の等高線図(その 1)

Fig. 5a Counter maps before and after landslide occurrence (Part 1 )
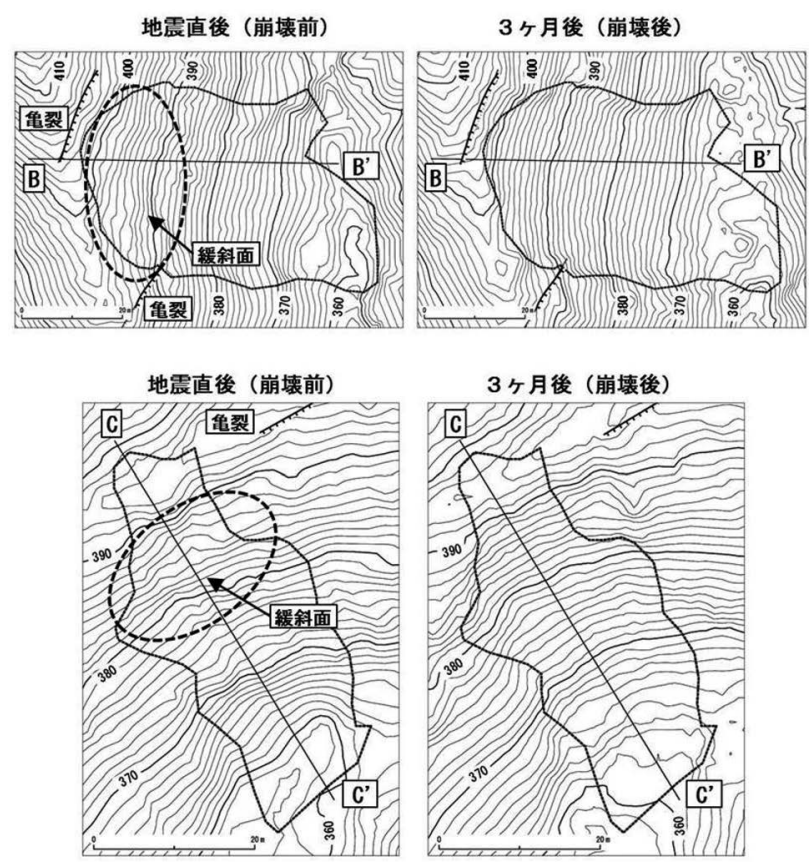

.... 地震 3 ヶ月後の崩壊範囲

図一5b 地震後に崩壊した斜面の崩壊前後の等高線図(その 2 )

Fig. 5b Counter maps before and after landslide occurrence (Part 2 )

-6で示す縦断面図でみるとやや凸型となる微地形の存 在が認められた。現地踏査から, 地震後に崩壊が発生し た斜面の崩壊頭部付近には，亀裂の発生が確認されるこ とが多かった（写真 -1$)$ 。 

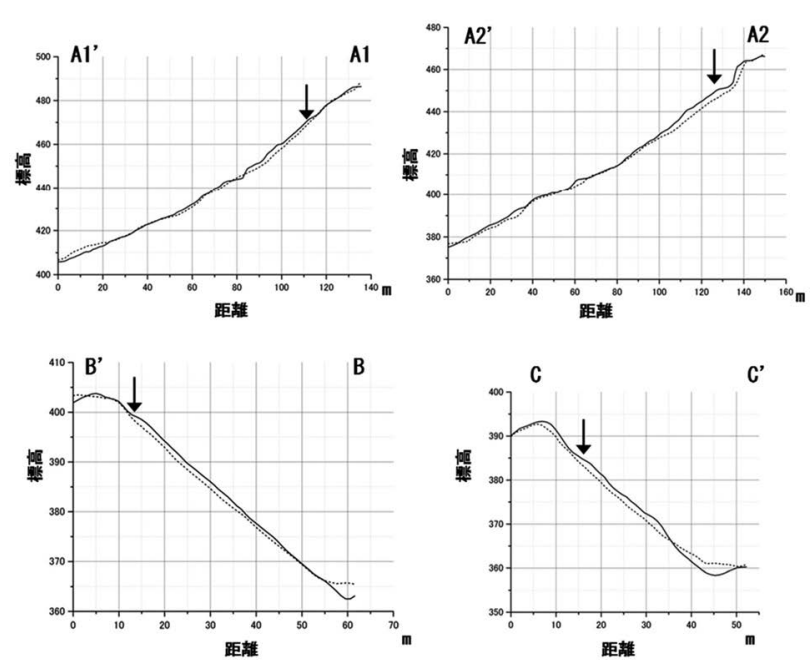

一...地震直後 (崩壊発生前)

図一6＼cjkstart地震後に崩壊した斜面の崩壊前後の縦断面図。矢印 は崩壊源頭部を示す。崩壊前は緩斜面であったこと が判断された。

Fig. 6 Slope profiles before and after landslide occurrence. Arrows show the source of the landslide. Source slope of the landslide determined to be gentle.

\section{2 崩壊が発生していない斜面における斜面崩壊の 兆候の検出と確認}

上述した微地形について，まだ崩壊が発生していない 斜面での存在を等高線図から判読したところ，崩壊が認 められない複数の斜面でも認められた。判読された緩斜 面のうち, 図一1に示すDの領域において現地を踏査し, 現況を確認した（図-7）。図-7aは領域Dの実体視空中 写真, 図-7bは2006年 9 月の航空レーザー測量データ から作成した $1 \mathrm{~m}$ 間隔の等高線図に上述した微地形が確 認される箇所を点線枠で示した図である。図ー7cは現地 を調査し，存在を確認した亀裂の実際の位置を示してい る。対象とした領域では空中写真，あるいはDEMより 作成した陰影図から亀裂そのものは判読することができ なかったが, 等高線図から 9 か所の緩斜面が判読され(図 -7b), このうち 8 か所で亀裂の発生が確認された（図 -7c)。亀裂は大きいものでも幅 $1.5 \mathrm{~m}$, 比高は $1 \mathrm{~m}$ 以下 であった（図－7d 1)。亀裂が確認された斜面では，亀 裂より下側の斜面が下方に移動し，その下端で斜面がせ り出している場所も認められた（図 $-7 \mathrm{~d} 2)$ 。緩斜面と 判読されなかった場所で亀裂が発生していたのは, 1ヶ所 のみであった（図 $-7 \mathrm{c}$, 図 $-9 \mathrm{~b}$ : 縦断面 $\mathrm{B}-\mathrm{B}^{\prime}$ 付近)。

\section{3 変形が認められる斜面における土質状況}

現地で亀裂を確認した斜面のうち, 図ー7cで示した亀 裂とその近傍の斜面において簡易貫入試験を行った。試 験を行った斜面の縦断面図とその結果を図ー8および 9 に示す。図ー8で示す亀裂より上方の斜面 (P 1 およびP 5 ）では，表層より 50〜 80cmの深さまではNc值が 5 以 下の軟弱な層がつづき，それより深くなると Nc值が40 以上の硬い層となる。一方で亀裂より下方の斜面では,

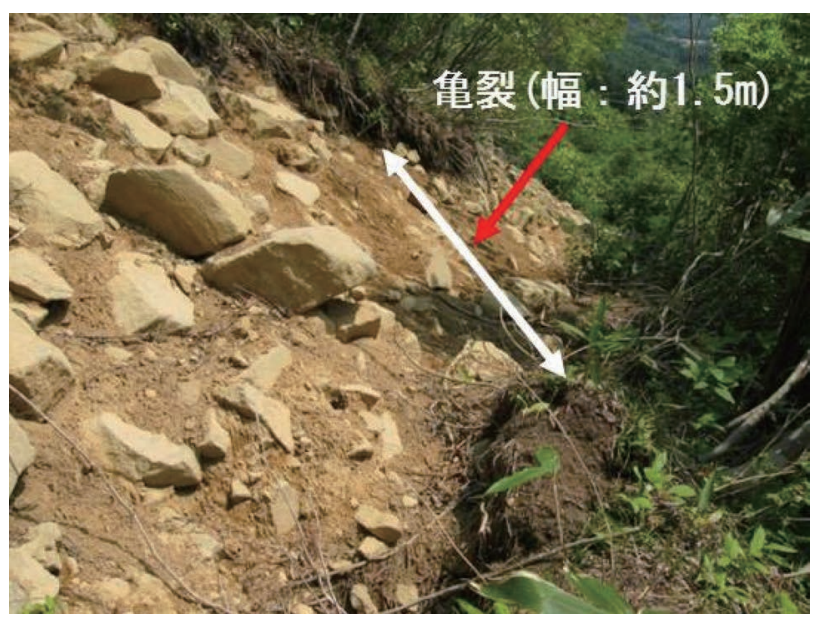

写真-1 A 1 の崩壊斜面源頭部で確認した亀裂。2009年 6 月26日撮影。写真の撮影位置は図一5aに示す。

Photo 1 Crack found near the top of the landslide (A1). The photo was taken on July 26, 2009, from the position shown in Fig. $5 \mathrm{a}$.

表層より50〜80 cmの深さまではNc值が 5 以下であるが, それより深くなると Nc值が大きくなり10～30程度の範 囲を示す層が100～250cmぐらいまでつづく。またこの 深さのNc值は深さによって值の変動が比較的ばらつく のが特徴である。その層内にNc值が 5 以下の軟弱な層 が深さ150〜 250cmの間に $10 \mathrm{~cm}$ 以下の層厚で現れ，その 後40以上の硬い層が現れた。

図ー9では同じ斜面において亀裂が存在する場所（図 $-9 \mathrm{~b}$ : 縦断面 $\mathrm{B}-\mathrm{B}^{\prime}$ 付近）と隣接する亀裂が存在しな い場所（図-9b：縦断面 $\mathrm{C}-\mathrm{C}^{\prime}$ 付近）を比較した。図一 9で示す斜面は等高線図からは緩斜面の存在が認識でき なかったが，縦断面図（図-9c）を比較すると，亀裂が 存在する縦断面B-B'では，亀裂より下方斜面が亀裂の 存在しない縦断面 $\mathrm{C}-\mathrm{C}^{\prime} に$ 比べ凸型の形状となっていた。 縦断面B-B'の亀裂付近（P6, P 7 ） および亀裂より下方 のP 8 では表層より 50〜 80cmの深さまではNc值が 5 以 下であるが，それより深くなると Nc值が大きくなり 10 〜 30程度の範囲を示す層が100〜 200 cmぐらいまでつづ き，その層内にP 6 とP 7 ではNc值が 5 以下, P 8 でも $\mathrm{Nc}$ 值が10以下の層が $10 \mathrm{~cm}$ 以下の厚さで現れ, その後 $\mathrm{Nc}$ 值 が40以上の硬い層が現れる構造となっていた。亀裂のあ る斜面の一番下方, せり出しょりも下方のP 9 は表層か ら $60 \mathrm{~cm}$ から $\mathrm{Nc}$ 值が大きくなり $80 \mathrm{~cm}$ 付近から $\mathrm{Nc}$ 值が 40 以上の硬い層となっていた。亀裂の存在しない縦断面C -C'では，表層より50〜80cmの深さまではNc值が 5 以 下の層がつづき，その後徐々に硬くなるが， Nc值が10 〜30の層はP11で $30 \mathrm{~cm}, \mathrm{P} 12 て ゙ 20 \mathrm{~cm}$ 程度の層厚であり, P10とP13ではほとんど認められなかった。また，Nc值 が 5 以下の層はP11で認められるものの，他の地点では 認められず, $100 \mathrm{~cm}$ よ深くなると Nc值が40以上の硬い 層となる構造であった。

土層構造を確認するために図ー8に示す地点において 

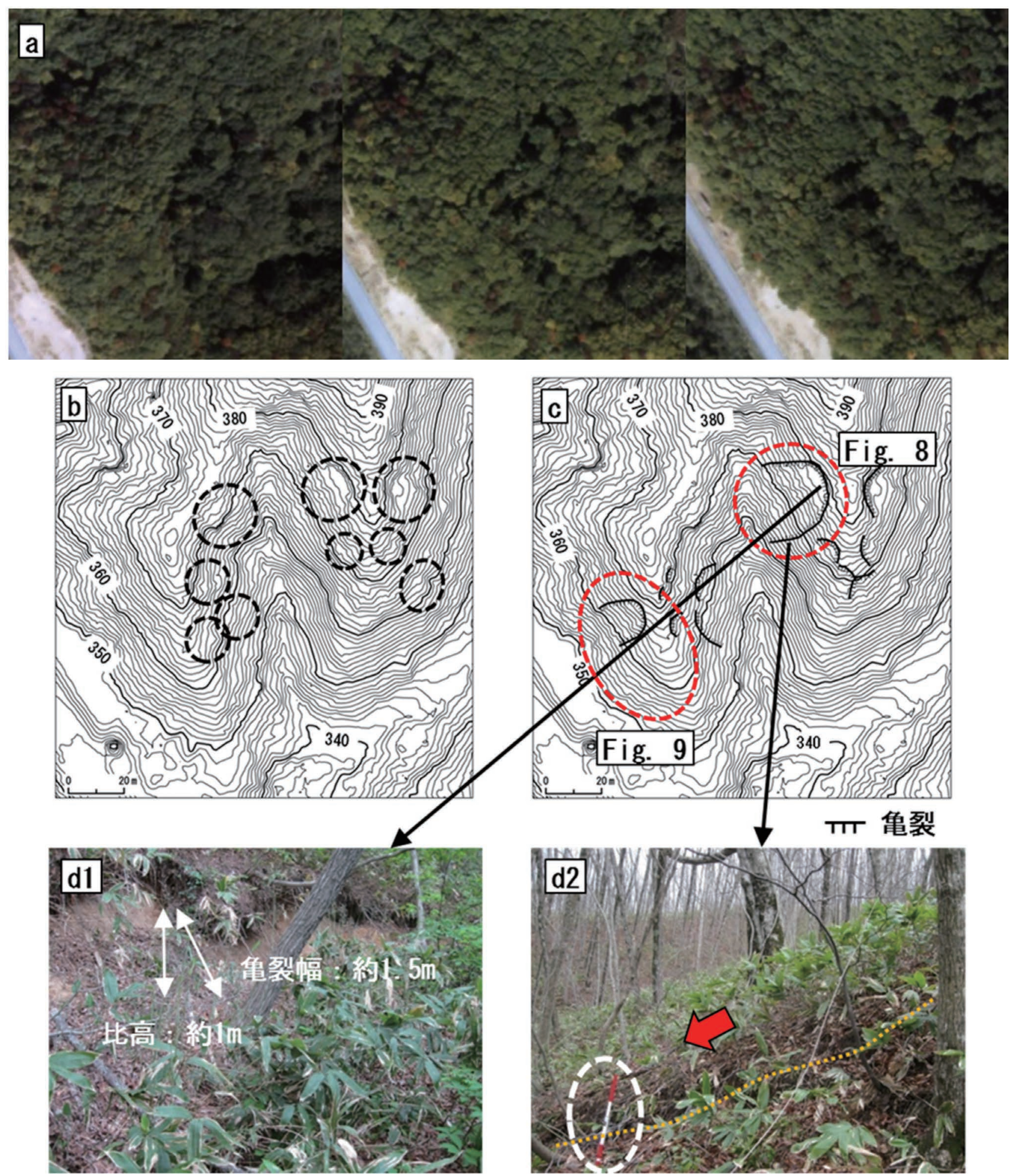

図-7 斜面変形を確認した斜面。a：実体視空中写真(国土地理院撮影(CTO-2008-5 C20-3, 4,5)。b : 地震 3 ヶ月後の航空レー ザー測量データより作成した $1 \mathrm{~m}$ 間隔の等高線図。点線で囲った領域は判読した緩斜面。c：現地調査で確認した亀裂の 位置。 d 1 : 亀裂の写真。 $\mathrm{d} 2$ : 亀裂（点線）よりその下方斜面（写真奥）が下流側（赤矢印）に変形し, 写真左下のポー ル付近 (白破線枠) でせり出しが認められる。

Fig. 7 Position of the transformation slope, as determined by LiDAR data analysis. a: Aerophotograph for stereoscopy. b : $1 \mathrm{~m}$ counter map using LiDAR data. Dotted line circle areas shows the gentle slopes based on LiDAR data analysis. $c$ : Position of cracks determined by field survey. $d 1$ : Crack. $d 2$ : Crack (dotted line). The far side of the crack in the photo moved downward (arrow), and was overhanging near the pole (dashed line circle). 

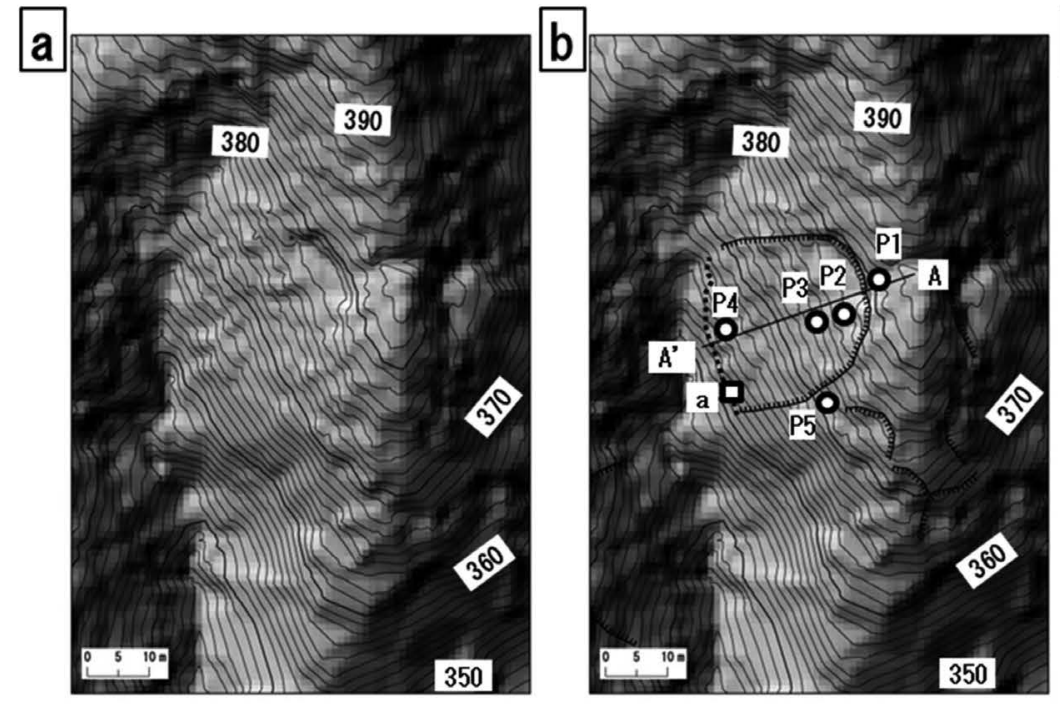

d
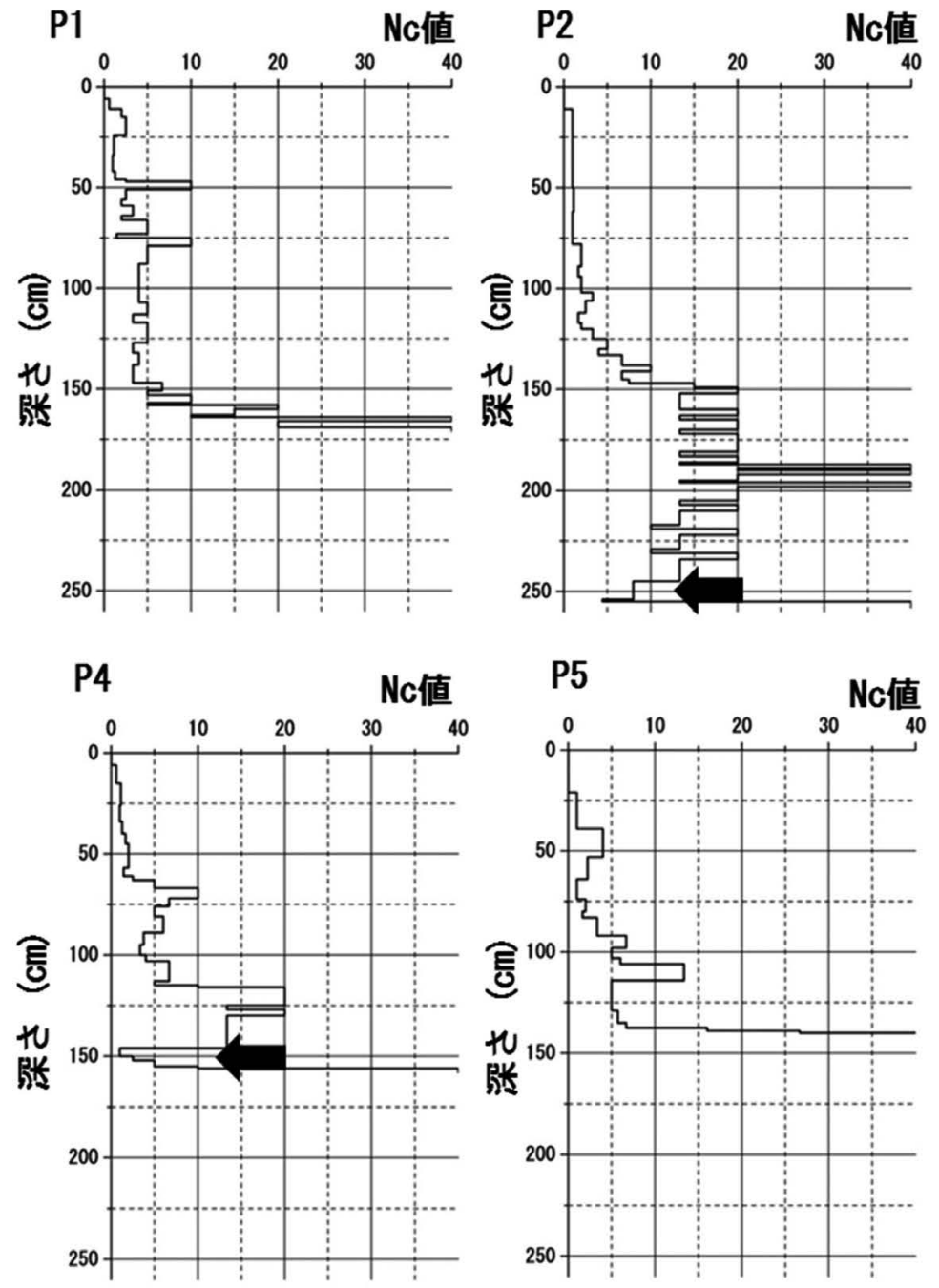
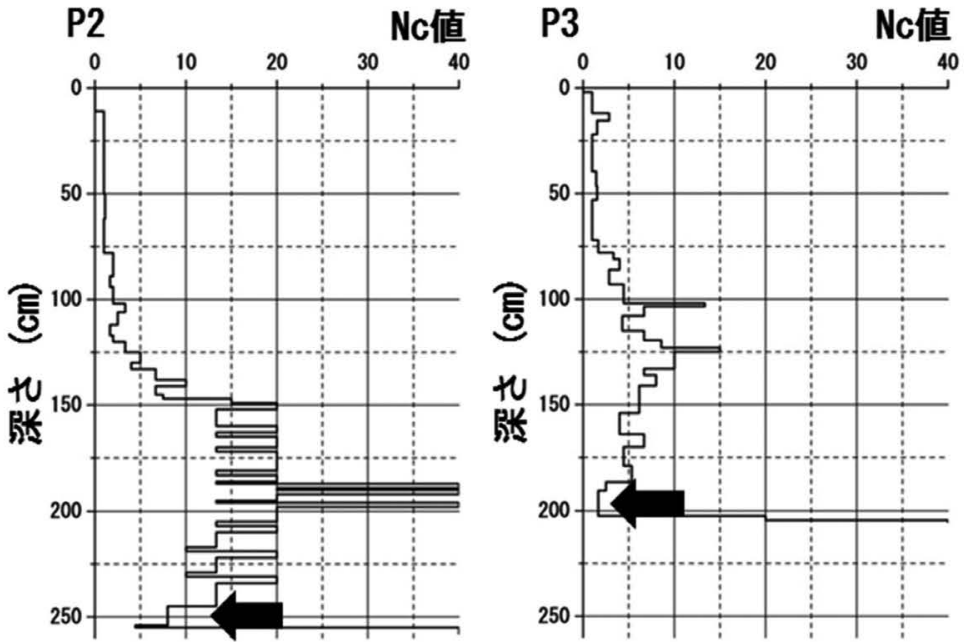

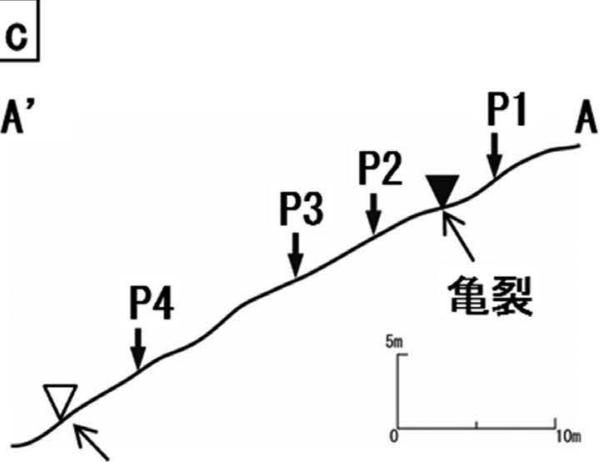

せり出し
せり出し O P1 P5 : 貫入試験調査地点 口 a : 土層断面調査地点

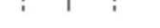

(n)


a

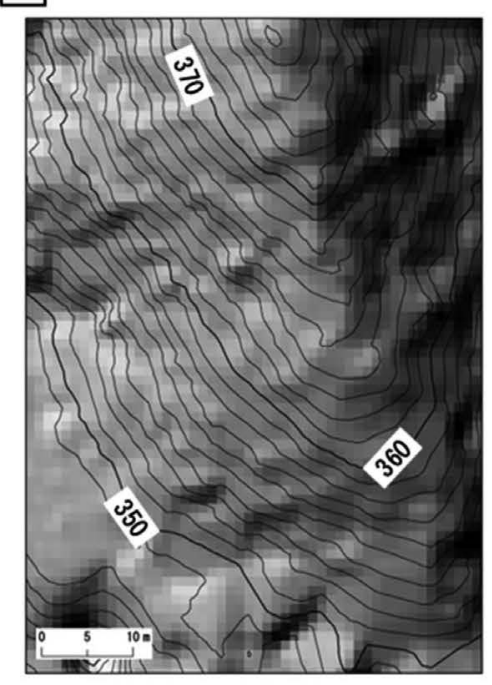

b

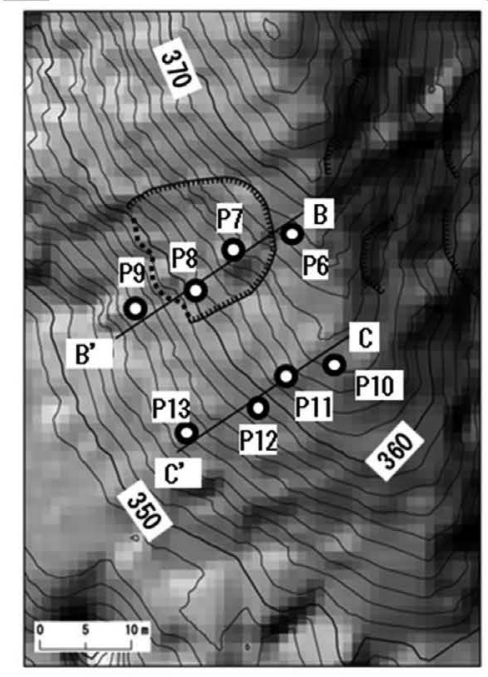

c

B'

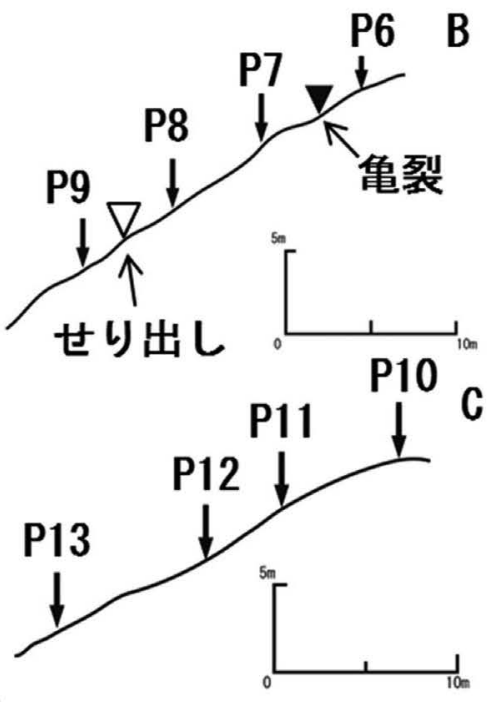

TT 亀裂

せり出し

OP6 P13 : 貫入試験調査地点
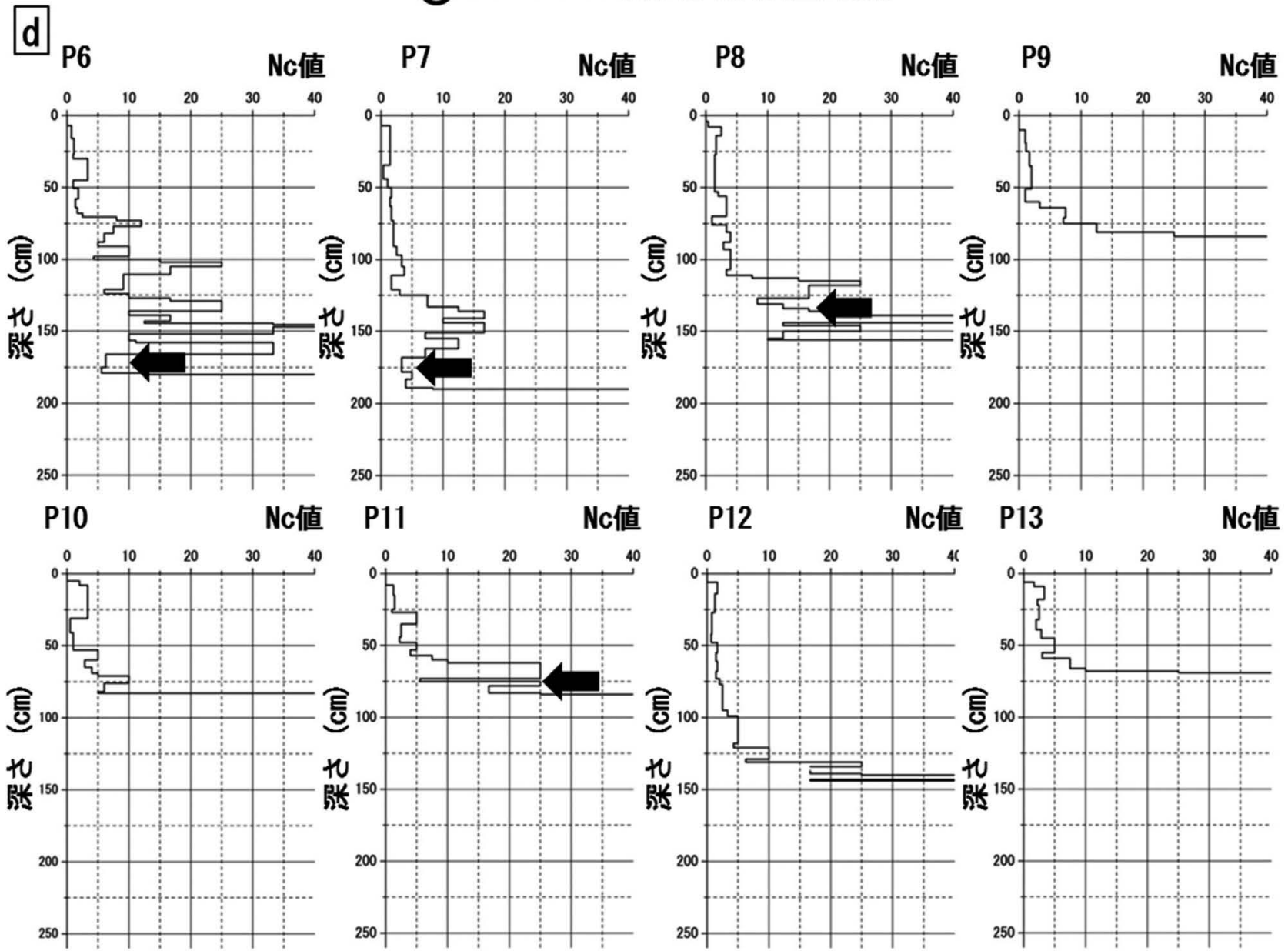

Nc値が10以上の層中に5以下

図-9 簡易貫入試験結果（その 2 )。調査した斜面の位置は図一7cに示す。a：陰影図（光源方位 $315^{\circ}$, 光源高度 $\left.45^{\circ}\right)$ および等 高線図 ( 1 m間隔)。b : 図一 $9 \mathrm{a}$ に亀裂および貫入試験調査地点, ラインB-B'およびC-C'の縦断面位置を示した図。c: インB-B'およびC-C'の縦断面図。d：調査位置ごとの貫入試験結果。

Fig. 9 Test results by dynamic cone penetrometer (part 2) from the surveyed slope shown in Fig. 7c. a: Hillshade (Azimuth : $315^{\circ}$, Altitude $: 45^{\circ}$ ) and $1 \mathrm{~m}$ contour map. b: Map overlaid cracks, surveyed points and profile lines of B-B' and $C^{-} C^{\prime}$ on Fig. 9a. c: Slope profiles on line $B^{-} B^{\prime}$ and $C^{-} C^{\prime}$. d: Test results by dynamic cone penetrometer on each point. 

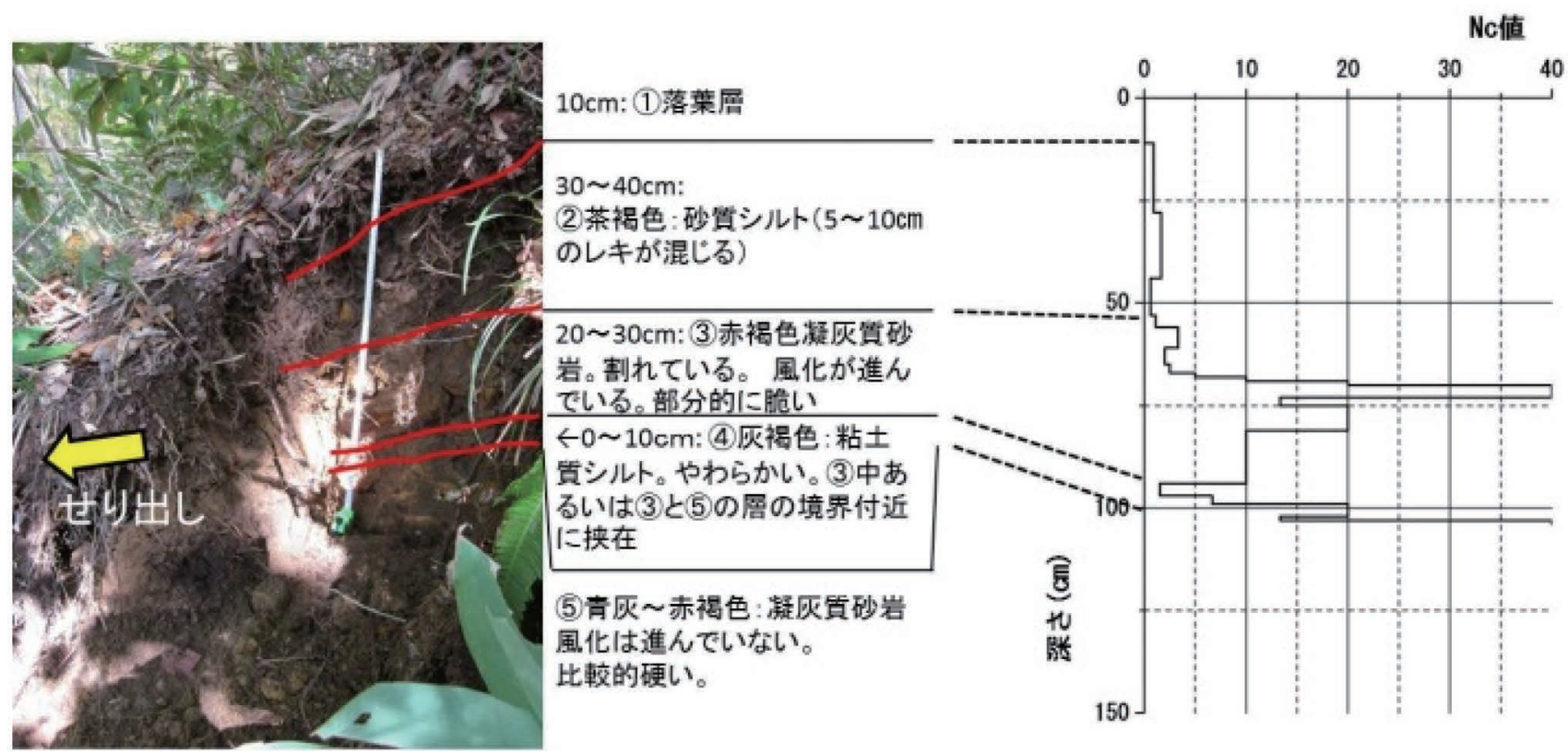

図-10 土層断面調査結果。調査位置は図一 $8 \mathrm{~b}$ に示す。

Fig. 10 Soil profile of the surveyed position shown in Fig. 8b.

掘削調査を行った。結果を図ー10に示す。調査の結果，

$\mathrm{Nc}$ 值が10～30程度に該当する層は風化が激しい岩盤で, 多くの割れ目が見られた。この割れた岩盤の硬さは場所 によって差が大きく，やわらかいものは手で割れる程度 の硬さしかなかった。図ー8で示したNc值が 5 以下の軟 弱な層と推定される場所はこの風化が激しい岩盤の層内 あるいは風化が進んでいない岩盤との境に挟在しており， 確認した場所では最大でも $10 \mathrm{~cm}$ 程度の層厚しかなかっ た。土質はシルトあるいは泥からなっていた。

\section{5. 考察}

地震後の降雨により崩壊が発生した斜面には，緩傾斜 で楕円あるいは馬蹄形の微地形が存在していたことが地 震直後（崩壊発生前）のデータと崩壊後のデー夕の比較 から推測された。小山ほか（2009）は2007年の集中豪雨 により鳥取県西部で発生した崩壊について,2000年に発 生した鳥取県西部地震（M7.3）によって斜面に形成さ れた亀裂を頭部として崩壊が発生した可能性を指摘して いるが，本調査地においても崩壊斜面の頭部周辺を現地 調査すると亀裂が存在することから，緩傾斜な地形上に は亀裂が発生していたことが推測され，この亀裂が弱線 となってその後の降雨により崩壊が発生したことが推測 された。

この推測を確認するため, 崩壊が発生していない斜面 において同様の地形が存在する場所を判読し，現地で龟 裂等の斜面の変形の痕跡を確認した。その結果，複数の 場所で亀裂の存在を確認することができた（図－7c）。 現地で確認した緩斜面では，その多くで亀裂が発生して いることから，今回の地震により亀裂が発生することに 伴って形成されたものと推測された。一方で, 亀裂が発

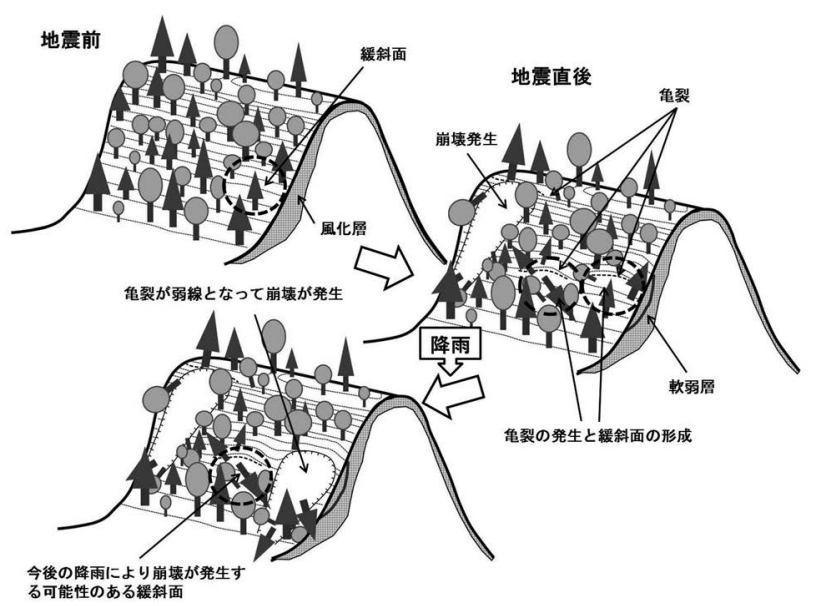

図一11調査地における地震直後からその後に崩壊に至るま での模式図

Fig. 11 Schematic diagram from immediately after the earthquake to landslide occurrence after the earthquake in the study area.

生していないものの，緩斜面の形成が認められる斜面も 存在した。このため，地震前に形成されていた緩斜面に 亀裂が発生した可能性もある。いずれにせよ地震後の降 雨によって崩壊した斜面には，地震によって亀裂が発生 した緩斜面が存在し，それらを頭部として崩壊が発生し たことが判断された。これらの亀裂は多くが空中写真， あるいはDEMより作成した陰影図から判読することが できなかった。これらの亀裂は幅が大きなものでも 1.5 $\mathrm{m}$ 以下，比高も $1 \mathrm{~m}$ 以下であったことから，今回使用し たDEMの解像度では判読が困難であったと考える。し かし，今回の調査手法のように等高線図および断面図を 作成し，緩傾斜で楕円あるいは馬蹄形，縦断面図では凸 
型の微地形を判読することにより，亀裂の存在する斜面 位置をある程度特定することは可能であると考える。な お, 調查地では稜線部にも多数の亀裂が存在するが，今 回の手法で特定することは難しかった。稜線付近はもと もと緩傾斜であり，今回報告する直線形の斜面の中から 半月または馬蹄形の局所的な緩傾斜の斜面を特定するよ うな手法で亀裂を捉えることは難しいと考える。稜線部 における亀裂の発生位置の特定については，村上ほか （2013b）が地震前後の航空レーザー測量データを比較 することにより稜線部の亀裂を特定したように，地震前 後のデー夕を比較することによって可能となると考える。

亀裂の発生した斜面の土質状況を調查するために簡易 貫入試験および土層断面調查を行った。試験結果から， 斜面に亀裂がある場所では，亀裂より下流の斜面（図一 8：P 2 P 4 ; 図-9：P $7 \sim \mathrm{P} 8$ ） では，地表より50〜 $80 \mathrm{~cm}$ の梁さから100〜250cmまでの深さにかけてNc值が 10〜30のやや硬い層が存在し, その中あるいは下層の Nc 值が40以上の硬い層との間にNc值が 5 以下の軟弱な層 の挟在が認められた。土層断面調査から， Nc值が10 30のやや硬い層は風化が激しく，破砕が進んだ岩盤層で あり， Nc值が 5 以下の軟弱な層がすべり面となってい ることが推察された。すべり面のNc值については地質 ごとに差が見られるが，既往の調查から新第三紀の地質 では多くは 5 〜 10 以下であることが報告されている（小 山内ほか, 2005）ことから，本調查で確認されたNc值が 5 以下の層はすべり面であると判断された。小山内ほか （2005）は崩壊した斜面周辺の岩盤風化層のNc值は10～ 20であることも報告しており, 今回の調查結果は既往の 結果を裏付けたものといえる。軟弱な層は，風化し破砕 が進んだ岩盤層内，あるいは下層の風化が進んでいない 岩盤層との境界付近に存在していることから，地震前か ら存在していた風化した岩盤層が，地震などによって破 砕が進み，層内に軟弱な層が形成されたことが推察され る。すべり面は今回の地震以前に形成されていた可能性 もあるが，少なくとも今回の地震によって亀裂の形成お よび崩壊の発生につながったことは確かであろうと考え る。一方で，亀裂より上部（図-8:P1, 図-9:P 6 ）お よびせり出しょり下部（図-9：P 9）あるいは亀裂が ない場所（図-8：P 5 ; 図-9:P10〜P13）ではP 6 を 除くと Nc值が10 30のやや硬い層は相対的に薄く，挟 在する Nc值が 5 以下の軟弱な層も $\mathrm{P} 6$ と $\mathrm{P} 11$ 以外は確認 されなかった。このことから，斜面内に打いて風化が進 んだ層が薄い場所では地震の際に緩斜面の形成および亀 裂の発生が起こらず，結果として崩壊が発生しなかった ことが考えられる。

以上の結果を模式的に示した図を図ー11に示す。今回 の地震後に発生した崩壊は, 斜面内の風化が進んだ層が 比較的厚い場所において, 地震の際に亀裂㧍よびすべり 面が形成され，そこを弱線としてその後の降雨によって 崩壊が発生したことが推測された。地震直後およびその
後の崩壊発生に至るまでには，このような風化層の脆弱 化・変形のプロセスが考えられる。

\section{6. まとめ}

本報告では2008年岩手・宮城内陸地震直後㧍よび 3 ケ 月後の 2008 年 9 月に計測された航空レーザー測量デー夕 を比較し，地震後の降雨によって崩壊が発生した斜面の 地形的特徴を明らかにした。今回の調查から，地震後に 崩壊が発生した斜面では崩壊発生前には楕円あるいは馬 蹄形の緩斜面が存在し，亀裂が発生していたと判断され た。このことは崩壊が発生していない斜面において上記 の微地形が形成されている簓所を特定し，現地調査を行 うことで確かめられた。亀裂が発生している緩斜面では $\mathrm{Nc}$ 值が10 30の風化層内，抒よび下層の $\mathrm{Nc}$ 值が 40 以上 の硬い層との境界付近にNc值が 5 以下のより軟弱な層 が形成されていたことから，地震後の降雨によって崩壊 が発生した斜面では，それらをすべり面として崩壊が発 生したことが推定された。西村・海堀（2002）は2001年 の芸予地震（M6.7）の影響を受けた地域では地震前の 斜面崩壊に必要な雨量の $6 \sim 8$ 割程度の降雨量で斜面崩 壊が発生する可能性を報告している。今回の調査によっ て亀裂の発生している斜面では軟弱な層が形成されてい ることが確認されていることから，今後，従来よりも小 さい降雨強度で崩壊が発生する可能性が考えられる。

調查地では地震前に航空レーザー測量が実施されてい ないこともあり，今回の調査によって確認された斜面内 の楕円あるいは馬蹄形の緩斜面といった微地形が地震前 から存在したかどうかは確認することができなかった。 また，今回の調查結果は斜面中腹に形成された緩斜面に おける地震にともなう亀裂の形成とその後の崩壊発生プ ロセスを報告するものであり，稜線部に発生した亀裂に ついては，今回報告する手法での特定は難しいことから， これについては崩壊発生プロセスも含め今後の検討課題 とした。これらのことは地震等の災害前後に航空レー ザー測量が実施された斜面において確認する必要がある と考えている。複数時期の航空レーザー測量データを比 較し, 斜面の変形箇所を抽出することは, 地震等の災害 によって斜面内で崩壊の危険性が高まった地点をより正 確に特定するとともに，今後の降雨にともなう崩壊発生 の危険性を評価するうえで有効であると考える。

\section{謝 辞}

現地調査に際しては岩手県および林野庁東北森林管理 局の関係各位より多大な協力をいただいた。弘前大学の 檜垣大助教授, 森林総研関西支所の多田泰之氏からは現 地調查に協力していただくとともに多くの助言をいただ いた。記して感謝申し上げます。なお，この研究はJSPS 科研費 JP24658146拈よびJP15K01272に基づいて行わ れた成果の一部である。 


\section{引用文献}

秋山幸秀（1997）：空中レーザー高密度計測の治山事業における活 用方法, 第37回治山研究発表会論文集, pp. 343-350.

川邊 洋 (1987）：地震による斜面崩壊の研究（I），（II），東京 大学農学部演習林報告, 77, pp. $49-142$.

栗駒山地熱地質グループ (1986)：1/10万栗駒地熱地質図説明書. 特殊地質図 $(21-3)$, 地質調查所, $26 \mathrm{p}$.

小山 敢・藤田亮 · 前田雄 - 多田泰之・落合博貴 - 三森利昭 · 大 丸裕武・村上 亘・河合隆行 · 岩村尚樹 (2009)：2007年 9 月 4 日の集中豪雨により鳥取県琴浦町で生じた斜面崩壊の特徵，砂 防学会誌, Vol. 62, No. 1, pp. 52-59.

村上 亘·大丸裕武・小川泰浩 - 黒川 潮 - 多田泰之・三森利 昭・安田正次・斎藤 仁 (2009) : 岩手宮城内陸地震において崩 壊斜面背後の山地稜線部に形成された亀裂, 2009年春季学術大会 日本地理学会発表要旨集, 217 .

村上 亘・大丸裕武・江坂文寿 (2013a)：2008年岩手・宮城内陸 地震後に発生した 2 次的な斜面崩壊の地形・地質的特徵, 森林 総合研究所研究報告, Vol. 12, No.1, pp. 23-40.

村上 亘·大丸裕武・向山 栄・川浪亜紀子 (2013b)：2008年岩 手·宮城内陸地震にともなう線状凹地の拡大と斜面の重力変形, 地形, Vol. 34, No.1, pp. 55-67.
西村 賢・海堀正博（2002）：地震動の影響を受けた地域における 降雨と斜面崩壊発生との関係について, 広島大学総合科学部紀 用 IV 理系編, 28 , pp. 35-47.

野口正二・安田幸生・多田泰之・三森利昭（2012）：2008年岩手· 宮城内陸地震災害地周辺の先行土湿野季節変動, 森林総合研究 所研究報告, Vol. 11, No. 3, pp. 151-160.

沖村 孝・鳥居宣之・永井久徳 (1998)：地震後の降雨により発生 した斜面崩壊メカニズムの一考察, 建設工学研究所論文報告 集, $40-$ B, pp. $97-114$.

小山内信智 - 内田太郎 - 曽我部匡敏 - 寺田秀樹 - 近藤浩一 （2005）：簡易貫入試験を用いた崩壊の恐れのある層厚推定に関 する研究，国土技術政策総合研究所資料, 261, 46p.

田結庄良昭・藤田智子（1996）：兵庫県南部地震とその後の降雨に よる斜面崩壊，応用地質，Vol. 37, No. 3, pp. 174-184.

富田陽子・桜井 亘・中 庸充（1996）：六甲山系における地震後 の降雨による崩壊地の拡大について, 新砂防, Vol. 48, No. 6, pp. $15-21$.

牛山素行（2002）：2002年 7 月 9 日～12日の台風 6 号による豪雨災 害の特徵, 自然災害科学, Vol.21, No. 3, pp. 285-297.

横山俊治・菊山浩喜（1997）：1995年兵庫県南部地震時に発生した 六甲花崗岩地域の斜面崩壊の運動様式と機構, 地すべり, Vol. 34, No. 3, pp. $17-24$.

（原稿受付2016年 9 月 2 日，原稿受理2016年12月21日） 